\title{
Influence of Reinforcement Type on Microstructure, Hardness, and Tensile Properties of an Aluminum Alloy Metal Matrix Composite
}

\author{
Belete Sirahbizu Yigezu*, Manas Mohan Mahapatra, Pradeep Kumar Jha \\ Department of Mechanical and Industrial Engineering, Indian Institute of Technology, Roorkee, India \\ Email: "kassa2000et@yahoo.com
}

Received April 5, 2013; revised May 23, 2013; accepted June 10, 2013

Copyright (C) 2013 Belete Sirahbizu Yigezu et al. This is an open access article distributed under the Creative Commons Attribution License, which permits unrestricted use, distribution, and reproduction in any medium, provided the original work is properly cited.

\begin{abstract}
This paper presents the results of the comparative study of as cast microstructures and mechanical properties viz yield strength, ultimate tensile strength, elastic modulus, percentage elongation, hardness, percentage porosity and fracture characteristic of $5 \mathrm{wt} \% \mathrm{SiC}$ and $\mathrm{Al}_{2} \mathrm{O}_{3}$ particulate reinforced $\mathrm{Al}-4 \% \mathrm{Cu}-2.5 \% \mathrm{Mg}$ matrix composites. These composite materials were prepared through stir casting process. Quantitative metallographic techniques were utilized to determine the average grain size of particles. The microstructures and tensile fracture characteristic of the representative samples of the composites were examined using optical microscope (OM), scanning electron microscopy (SEM), energy dispersive X-ray analysis (EDX) and X-ray diffraction (XRD) techniques. The experimental results demonstrate a fairly uniform distribution of $50.8 \mu \mathrm{m} \mathrm{Al}_{2} \mathrm{O}_{3}$ and $49.2 \mu \mathrm{m} \mathrm{SiC}$ spherical particles with some clustering in few areas. At the interfaces of $\mathrm{Al}_{2} \mathrm{O}_{3}$ and the matrix, $\mathrm{MgO}$ and $\mathrm{MgAl}_{2} \mathrm{O}_{4}$ were observed. Similarly, $\mathrm{Al}_{4} \mathrm{C}_{3}$ was formed at the interfaces between $\mathrm{SiC}$ and the matrix. The mechanical property test results revealed that, for the same weight percentage of reinforcement, $\mathrm{Al}-4 \% \mathrm{Cu}-2.5 \% \mathrm{Mg} / 5 \mathrm{wt} \% \mathrm{SiC}$ composite exhibit a $15.8 \%, 16.4 \%, 4.97 \%$ and $10.8 \%$ higher yield strength, ultimate tensile strength, elastic modulus, and hardness, respectively. On the other hand, even if some porosity was observed in the $\mathrm{Al}_{2} \mathrm{O}_{3}$ reinforced composite, the percentage elongation (ductility) was $31 \%$ higher than that of $\mathrm{SiC}$ reinforced composite. The tensile specimen of $\mathrm{SiC}$ reinforced composite failed in a brittle fashion without neck formation, whereas the $\mathrm{Al}_{2} \mathrm{O}_{3}$ reinforced composite failed in a ductile fashion with noticeable neck formation.
\end{abstract}

Keywords: $\mathrm{Al}_{2} \mathrm{O}_{3}$; Casting; Intermetalics; Metal Matrix Composites; Metallography; $\mathrm{SiC}$

\section{Introduction}

Industrial technology is growing at a very rapid rate and consequently there is an increasing demand for new materials [1]. Conventional metals and alloys have limitations in achieving good combination of strength, toughness, wear resistance, high temperature performance and corrosion resistance. Therefore, material researchers' have diverted their focus from monolithic to composite materials [2]. A composite material is made by combining two or more physically distinct phases whose combination produces aggregate properties that are different from those of its constituents. Composite materials can be classified as: 1) Metal Matrix Composite (MMCs), which is the mixture of ceramics and metals; 2) Ceramic Matrix Composites (CMCs), in which two ceramic materials are imbedded together for improved properties, especially in

${ }^{*}$ Corresponding author. high temperature applications; and 3) Polymer Matrix Composites (PMCs), where thermosetting resins are most widely used as the matrix [3]. Among these composite materials, metal matrix composites are the most widely used.

MMCs combine high strength, ductility and high temperature resistance properties of metals together with the stiff and strong, but brittle character of ceramics. Aluminium and silicon carbide, for example, have very different mechanical properties: Young's moduli of 70 and $400 \mathrm{GPa}$, coefficients of thermal expansion of $24 \times 10^{-6}$ and $4 \times 10^{-6} /{ }^{\circ} \mathrm{C}$, and yield strengths of 35 and $600 \mathrm{MPa}$, respectively $[4,5]$. By combining these materials, superior properties such as high strength, high stiffness, high service temperature, high electrical and thermal conductivity, good wear resistance, and low coefficient of thermal expansion can be achieved. These unique properties of MMCs provide a better option for structural applica- 
tions primarily related to automobiles and aerospace sectors [5-7].

The addition of high strength, high modulus refractory particles such as $\mathrm{SiC}, \mathrm{TiC}, \mathrm{B}_{4} \mathrm{C}, \mathrm{Al}_{2} \mathrm{O}_{3}, \mathrm{MgO}, \mathrm{TiO}_{2}$, etc. to a ductile metal matrix produce a material whose mechanical properties are intermediate between the matrix alloy and the ceramic reinforcements [8-10]. The reinforcement materials are basically classified as: 1) Continuous or discontinuous fibres; 2) Whiskers; 3) Particles; and 4) Laminated reinforcements [8,11]. In recent years, particulate-reinforced metal-matrix composites have attracted considerable attention due to their cost-effectiveness, isotropic properties, and their ability to be processed using similar technology used for monolithic materials $[9,10]$. The main processing techniques for MMCs are 1) liquid state processing; 2) semisolid processing; and 3) powder metallurgy. However, particulate reinforced $\mathrm{Al}$ composites can be processed more easily by the liquid state i.e. melt-stirring process. Melt stir casting is an attractive processing method since it is relatively inexpensive and offers a wide selection of materials and processing conditions [12,13].

So far considerable research work had conducted to investigate the effects of reinforcement type and volume fraction on the microstructure and mechanical properties of numerous aluminium alloys. However, in the contemporarily literatures there is no published work particularly emphasized on $\mathrm{SiC}$ or $\mathrm{Al}_{2} \mathrm{O}_{3}$ particulates reinforced $\mathrm{Al}-4 \% \mathrm{Cu}-2.5 \% \mathrm{Mg}$ matrix composites. The intent of the present study is therefore, to examine the comparative effects of the addition of $5 \mathrm{wt} \% \mathrm{SiC}$ and $\mathrm{Al}_{2} \mathrm{O}_{3}$ particulate reinforcements on the microstructure and mechanical properties of $\mathrm{Al}-4 \% \mathrm{Cu}-2.5 \% \mathrm{Mg}$ matrix.

\section{Experimental Work}

\subsection{Materials and Preparation of Composites}

In this study, $\mathrm{Al}-4 \% \mathrm{Cu}-2.5 \% \mathrm{Mg}$ foundry alloy was used as the matrix material and 400 mesh size $(18 \mu \mathrm{m}$ $40 \mu \mathrm{m}) 5 \mathrm{wt} \% \mathrm{SiC}$ and $\mathrm{Al}_{2} \mathrm{O}_{3}$ particles were used as the reinforcement. Table 1 presented the chemical composition of the matrix material. The melting process was carried out in a muffle furnace with graphite crucible. Initially, $\mathrm{Al}-4 \% \mathrm{Cu}-2.5 \% \mathrm{Mg}$ foundry alloy was charged into the crucible and heated to about $700^{\circ} \mathrm{C}$ till the entire alloy was melted. The ceramic particles were preheated to $850^{\circ} \mathrm{C}$ for two hours before incorporation into the melt. The preheated $\mathrm{SiC} / \mathrm{Al}_{2} \mathrm{O}_{3}$ particles were then added at a uniform rate. During the incorporation of reinforcement particles the melt was stirred with mechanical stirrer at the speed of $700 \mathrm{rpm}$. After the matrix alloy fully melted a small amount of degasser $\left(\mathrm{C}_{2} \mathrm{Cl}_{6}\right)$ was added to minimize the presence of hydrogen gas in the melt. A small amount of magnesium $(<2 \mathrm{wt} \%)$ was also added to im- prove the wettability. The mixture was poured into the steel mould of size $35 \times 35 \times 260 \mathrm{~mm}^{3}$ for the preparation of cast blanks. The mould was also preheated to $350^{\circ} \mathrm{C}$ for $1 \mathrm{~h}$ to obtain uniform solidification. All the melting process was carried out under the cover of argon gas. $\mathrm{SiC}$ and $\mathrm{Al}_{2} \mathrm{O}_{3}$ particulate reinforced composites were produced separately using the same technique and similar processing parameters.

\subsection{Microstructural Characterization}

Microstructural samples were taken from various portions of the experimental composites. The surface of the specimens were initially polished using 120, 220, 400, $600,800,1000,1500$ and 2000 grit size water proof $\mathrm{SiC}$ emery papers. Then, polishing was carried out on a disc polisher with $\mathrm{Al}_{2} \mathrm{O}_{3}$ suspension on velvet cloth, until a mirror finish surface was obtained. Finally samples were etched using Keller's reagent $\left(2.5 \% \mathrm{HNO}_{3}, 1.5 \% \mathrm{HCl}\right.$, $1 \% \mathrm{HF}$ and $95 \% \mathrm{H}_{2} \mathrm{O}$ by volume) to achieve a better microstructural observation. Microstructural characterization was done using scanning electron microscope (SEM). For identifying the compositional elements and confirming the formation of $\mathrm{SiC} / \mathrm{Al}_{2} \mathrm{O}_{3}$ particles and the presences of other intermetalic phase X-ray diffraction (XRD) and energy dispersive X-ray analysis (EDX) was carried out.

\subsection{Mechanical Property Test}

Vickers bulk hardness at load of $5 \mathrm{~kg}$ was carried out on the composite samples after polishing with a fine grained emery papers. For hardness measurement at least seven indentations in $2 \mathrm{~mm}$ gap have been made and the average of these readings was reported as the hardness of the corresponding material. Representative tensile specimens from different parts of the cast ingot were machined at $5.0 \mathrm{~mm}$ diameter and $25 \mathrm{~mm}$ gage length. After machining, the gage surface of the specimens was mechanically polished using 400 and 600 grained emery papers to remove scratches and machining marks. Three test specimens were used for each run and the mean value were reported as a result. The $0.2 \%$ proof stress, ultimate tensile strength (UTS), elastic modulus (E) and percentage elongation $(\% \mathrm{EL})$ were determined based on the stressstrain curves of the examined test specimens. The fracture surfaces of the representative samples were examined by SEM to determine the failure mechanisms.

Table 1. Chemical composition of Al-4\% Cu-2.5\% Mg matrix.

$\begin{array}{cccccccccc}\text { Element } & \mathrm{Cu} & \mathrm{Mg} & \mathrm{Si} & \mathrm{Zn} & \mathrm{Mn} & \mathrm{Fe} & \mathrm{Sn} & \mathrm{Ti} & \mathrm{Al} \\ \mathrm{wt} \% & 4.26 & 2.91 & 1.46 & 0.80 & 0.38 & 0.37 & 0.35 & 0.18 & \text { Balance }\end{array}$




\subsection{Porosity Measurement}

In a composite, the proportions of the matrix and reinforcement are expressed either as the weight fraction $(w)$, which is relevant to fabrication, or the volume fraction $(v)$, which is commonly used in property calculations. By relating weight and volume fractions via density $(\rho)$, the following expression is obtained ( $m$ stands for matrix and $r$ for reinforcement material): [14]

$$
\rho_{c}=\rho_{r} V_{r}+\rho_{m} V_{m}
$$
[14]

The above expression can be generalized as follows:

$$
X_{c}=X_{m} V_{m}+X_{p} V_{p}
$$

In this study the theoretical density of the composites was obtained by rule of mixture and the experimental densities determined by the Archimedes principle of weighing small pieces cut from the composite billet, first in air and then in water with analytical balance of a measurement precision $0.0001 \mathrm{~g}$. Four specimens for each percent weight fraction were used for density measurement. Then, the porosity of the composite samples was determined by using the theoretical and experimental densities, according to the equation:

$$
\text { Porosity }=\frac{d_{t}-d_{e}}{d_{t}}
$$

where $d_{t}$ and $d_{e}$ represent the theoretical and experimental densities, respectively [15].

\section{Results and Discussion}

\subsection{Microstructure Analysis}

The most important factor to achieve a homogeneous property of discontinuously reinforced composites material is the uniform dispersion of the reinforcement particles. Therefore, the appearance of the microstructure could give an insight into the quality of the composite [16]. Figures 1 and 2 demonstrate the SEM micrographs and EDX patterns of the as cast experimental composites.
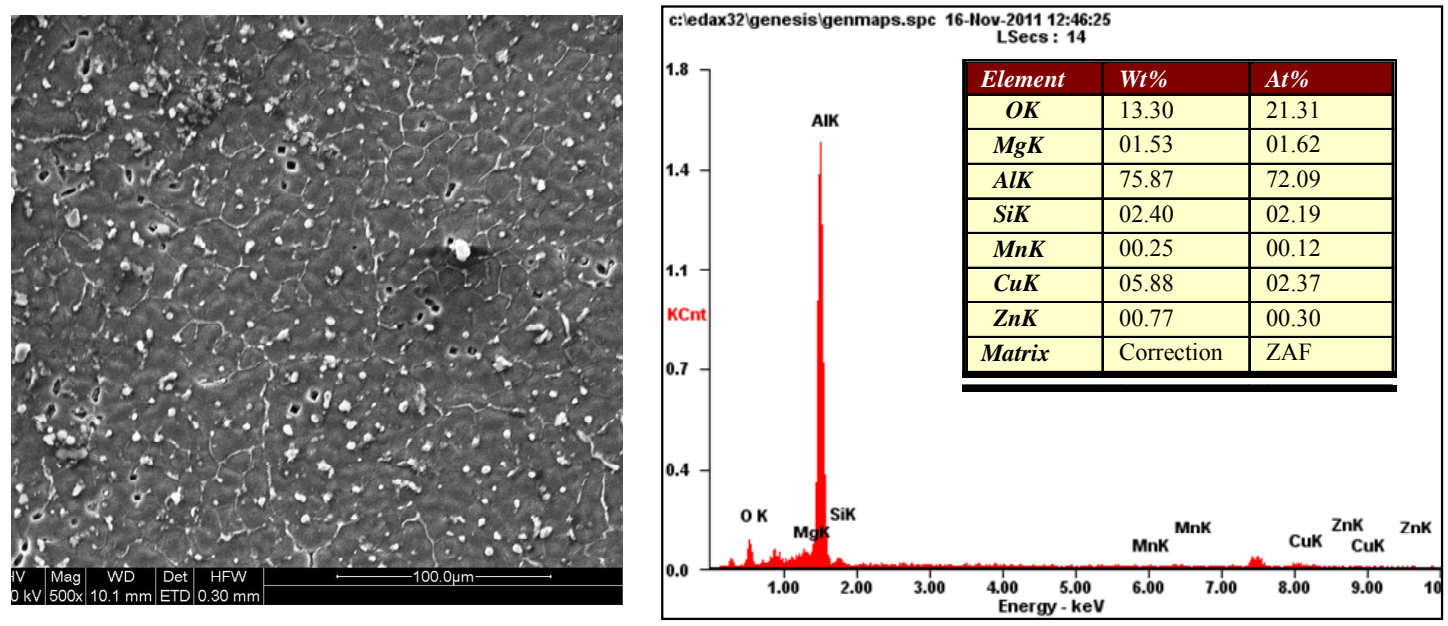

Figure 1. The SEM micrograph and EDX spectra of $\mathrm{Al}-4 \% \mathrm{Cu}-2.5 \% \mathrm{Mg} / 5 \mathrm{wt} \% \mathrm{Al}_{2} \mathrm{O}_{3}$.
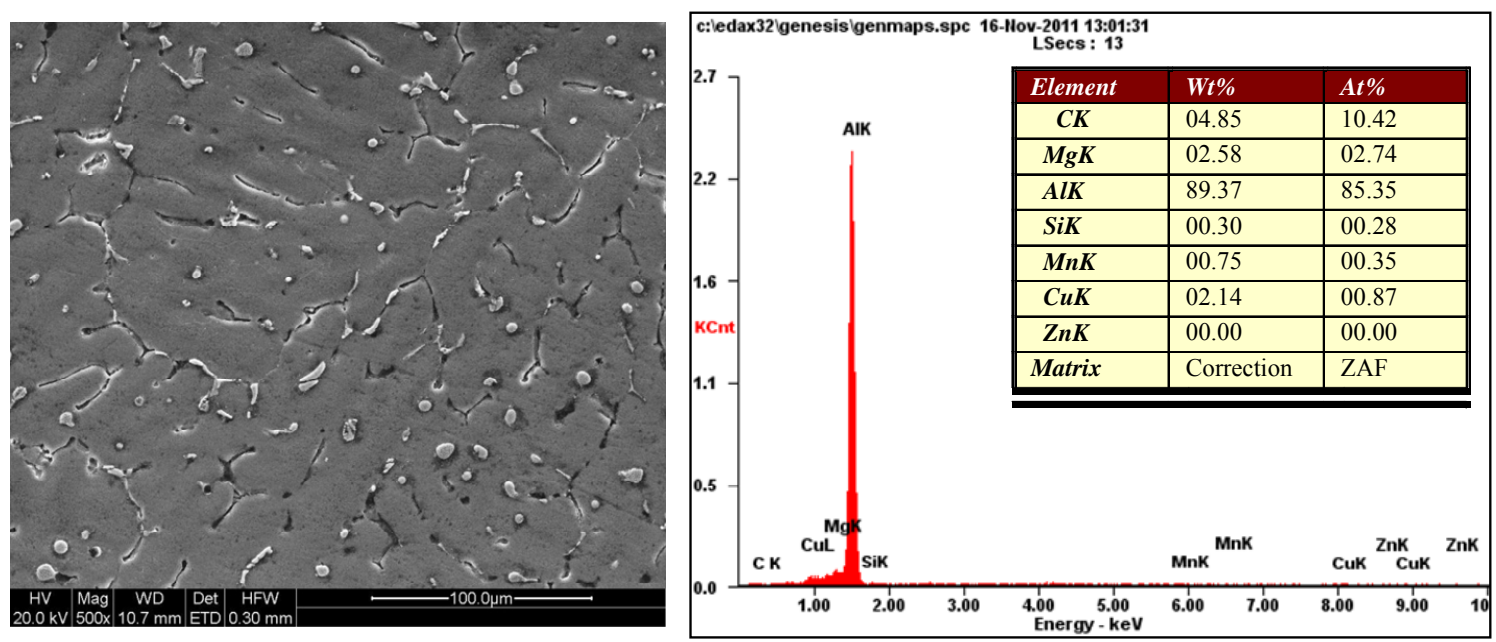

Figure 2. The SEM micrograph and EDX spectra of Al-4\% Cu-2.5\% Mg/5 wt\% SiC. 
The microstructures observations revealed that the rein forcement particles are almost spherical in shape and their distribution is reasonably uniform throughout the matrices in a company with clustering of particles and porosity at some locations. The white spots characterize $\mathrm{Al}_{2} \mathrm{O}_{3}$ and $\mathrm{SiC}$ particles, whereas, the black spots exposed the presences of porosity. Particles clustering may occur due to the insufficient stirring speed and stirring time, whereas, the porosity may be attributed to the dissolved gases and air bubbles sucked into the melt while adding the argon gas and the ceramic powder to the melt via the vortex during the mechanical string. But the degree of clustering and porosity was found more in the $\mathrm{Al}_{2} \mathrm{O}_{3}$ reinforced composite.

It is expected that the contact between the reinforcing particles and $\mathrm{Al}$ melt would result in an interaction layer which improves wetting between the two constituents. The type of interaction layer depends on the elements present at the interface during processing [13]. The interfacial reaction between the metal matrix and reinforcement in metal matrix composites (MMCs) is very important because strong interfacial bonding permits the transfer and distribution of the load from the matrix to the reinforcement. Therefore, the nature of the interface is one of the most important factors to consider when designing a MMC [17]. The XRD pattern of the examined material revealed that $\mathrm{CuAl}_{2}$ and $\mathrm{MgAl}_{2} \mathrm{O}_{4}$ occurred in the interfaces between $\mathrm{Al}_{2} \mathrm{O}_{3}$ and the matrix. Similarly, $\mathrm{Al}_{4} \mathrm{C}_{3}$ and $\mathrm{CuAl}_{2}$ were formed at interfaces between $\mathrm{SiC}$ and the matrix. The presences of such brittle inter-metallic phases substantially affect the strength of the bond between the matrix and the reinforcement. In a consequence the load transfer process will be affected and that causes the local stresses in the microstructure raised and this may lead to particle cracking and as a result the mechanical properties will be lower. Figures $\mathbf{3}$ and $\mathbf{4}$ illustrate the XRD patterns of the experimental composites.

\subsection{Mechanical Properties Test Analysis}

Reinforcing aluminium alloys with ceramic particles such as $\mathrm{Al}_{2} \mathrm{O}_{3}$ or $\mathrm{SiC}$ have bring a substantial mechanical property change over conventional aluminium alloys, like enhancing strength and hardness and improved wear resistance. However, these reinforcing particles have significantly reduced ductility compared to unreinforced alloys. The results of our study revealed that for the same volume fraction of particulates, $\mathrm{Al}-4 \% \mathrm{Cu}-2.5 \% \mathrm{Mg}$ matrix reinforced with $\mathrm{SiC}$ exhibit $15.8 \%, 16.4 \%, 4.97 \%$ and $10.8 \%$ higher $0.2 \%$ proof stress, ultimate tensile strength, elastic modulus, and hardness, respectively. On the other hand, the $\mathrm{Al}_{2} \mathrm{O}_{3}$ reinforced composite demonstrate a $31 \%$ higher percentage elongation than that of the $\mathrm{SiC}$ reinforced composite. This may be attributed to the relative lower hardness value of $\mathrm{Al}_{2} \mathrm{O}_{3}$ particles $\left(\mathrm{Al}_{2} \mathrm{O}_{3}\right.$ -

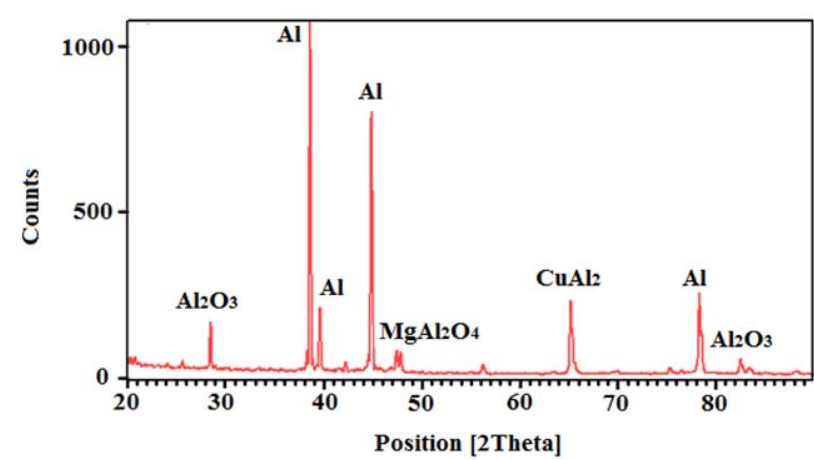

Figure 3. The XRD pattern of $\mathrm{Al}-4 \% \mathrm{Cu}-2.5 \% \mathrm{Mg} / 5 \mathrm{wt} \%$ $\mathrm{Al}_{2} \mathrm{O}_{3}$ composite.

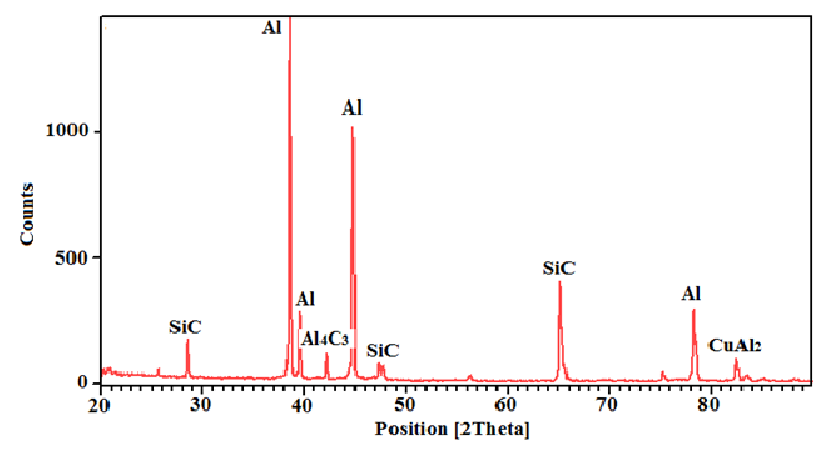

Figure 4. The XRD pattern of $\mathrm{Al}-4 \% \mathrm{Cu}-2.5 \% \mathrm{Mg} / 5 \mathrm{wt} \%$ $\mathrm{SiC}$ composite.

$1175 \mathrm{~kg} / \mathrm{mm}^{2}<\mathrm{SiC}-2800 \mathrm{~kg} / \mathrm{mm}^{2}$ ) and the presence of relatively higher reinforcement particles clustering in the cast $\mathrm{Al}-4 \% \mathrm{Cu}-2.5 \% \mathrm{Mg} / 5 \mathrm{wt} \% \mathrm{Al}_{2} \mathrm{O}_{3}$ composite. It has been well known that the clustered reinforcement particles hindered the uniform distribution of particles, as a result the porosity level elevated in these regions and which causes to deteriorate the mechanical properties. In addition, the average grain size of the $\mathrm{SiC}$ reinforced composite is a little bit lower than that of $\mathrm{Al}_{2} \mathrm{O}_{3}$ reinforced composite. The lower the $\mathrm{SiC}$ particle size resulted in better mechanical properties. Moreover, the large strength and modulus improvements indicate that the strength of the bond between $\mathrm{SiC}$ and the matrix is higher and as a result the load transfer was more efficient in the $\mathrm{Al}-4 \% \mathrm{Cu}-2.5 \% \mathrm{Mg} / 5 \mathrm{wt} \% \mathrm{SiC}$ composite. The reduction in ductility in case of $\mathrm{SiC}$ reinforced composite can be attributed to the relative higher hardness of the $\mathrm{SiC}$ particles that is prone to localized crack initiation and increased embrittlement effect due to local stress concentration sites at the reinforcement-matrix interface. Figure 5 shows the results of mechanical property measurements.

Previous experimental results also demonstrate similar observations. High strength $\mathrm{Al}$ alloys reinforced with either $\mathrm{Al}_{2} \mathrm{O}_{3}$ or $\mathrm{SiC}$ particulates are among the most promising composite material systems. Evidently, the main drawback of these composite materials is their very low 
ductility, which is limited by the nucleation of voids by reinforcement cracking [18]. Composite materials containing hard particles have high hardness, but their yield stress does not increase in the same proportion due to limited load bearing by the particles caused by shape and size [19]. It was also reported that during the production process of MMCs, some porosity is normal, because of gas entrapment during vigorous stirring, air bubbles entering the slurry either independently or as an air envelope to the reinforcement particles, water vapour on the surface of the particles, hydrogen evaluation, shrinkage during solidification, and volume fraction of reinforcement material. The presence of porosity, consequently, decreases most of the mechanical properties of cast MMCs. Failures initiated from the pores within the matrix material, particle fracture and reinforcement-matrix interface are due to voids coalescence, reduction of ductility, and reduced MMC cross section [20,21]. It has also been observed that clustered reinforcement distributions are deleterious to mechanical properties [22].

\subsection{Fractographic Test Analysis}

SEM micrographs of the fractured surface of the experimental composites are shown in Figure 6. It can be seen that the tensile failure of $\mathrm{Al}-4 \% \mathrm{Cu}-2.5 \% \mathrm{Mg} / 5 \mathrm{wt} \%$ $\mathrm{Al}_{2} \mathrm{O}_{3}$ composite consists of several sized dimples along with noticeable neck formation prior to fracture, which is typically a ductile fracture. In agreement with an earlier work of Daoud et al. [23], the fracture surface of the composites reinforced with $\mathrm{Al}_{2} \mathrm{O}_{3}$ particulates essentially consists of a bimodal distribution of dimples. The large size dimples are associated with the particulates and small dimples are associated with ductile fracture of the matrix. On the other hand, the tensile specimen of $\mathrm{Al}-4 \%$ $\mathrm{Cu}-2.5 \% \mathrm{Mg} / 5 \mathrm{wt} \% \mathrm{SiC}$ composite fractured in a brittle fashion without any noticeable necking formation and few numbers of fine dimples. This may be due to the void nucleation, growth, and coalescence occurred rapidly. It is well known that voids nucleation, growth, and coalescence contributed to the final fracture of the matrix.

The other possible reason for the brittle fracture nature of the $\mathrm{SiC}$ reinforced composite may be the presence of weak intermetalic phases like $\mathrm{Al}_{4} \mathrm{C}_{3}$. The existence of this detrimental intermetalic phase activates a different fracture mechanism, the material failing by the nucleation, growth and coalescence of voids and these voids subsequently grow by plastic straining and as a result final fracture occurs suddenly by localized necking of the intervoid matrix. Previous research work also demonstrated that there are three modes of failure typically occur in metal matrix composites: 1) cracking of the reinforcing particles; 2) partial debonding at the particle/ matrix interface resulting in the nucleation of voids; and 3 ) the growth and coalescence of voids in the matrix.

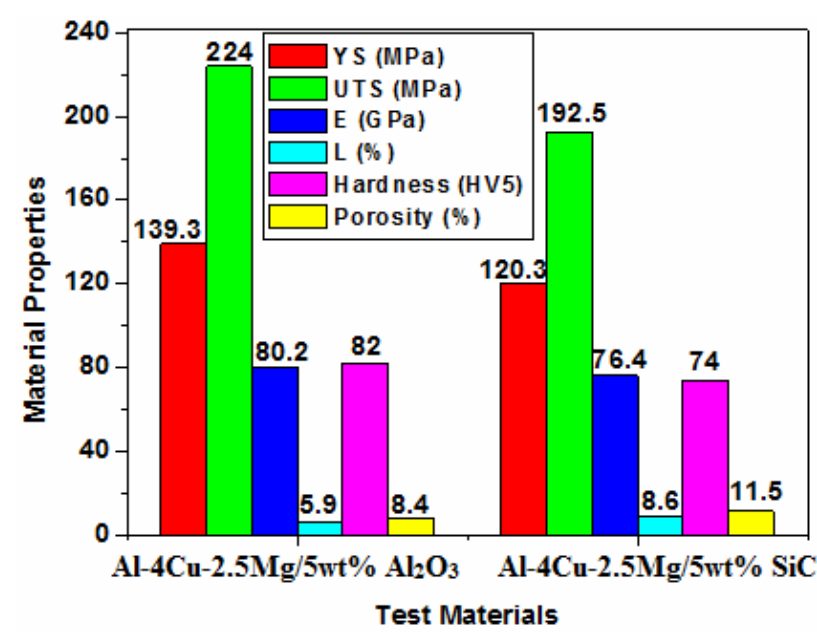

Figure 5. Variation of $0.2 \%$ proof stress, ultimate tensile strength, elastic modulus, \% elongation, bulk hardness and $\%$ porosity as a function of reinforcement type.

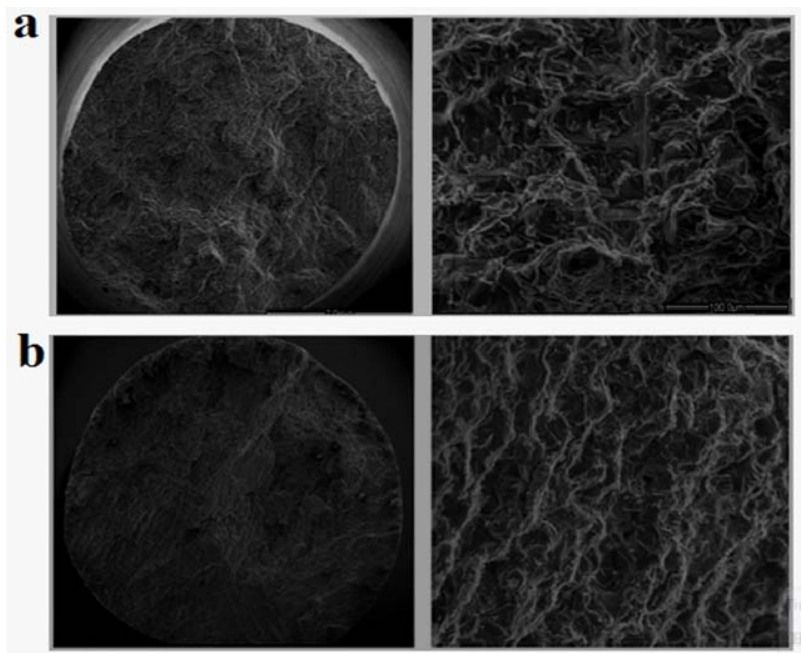

Figure 6. SEM micrograph of the tensile fracture surface of: (a) $\mathrm{Al}-4 \% \mathrm{Cu}-2.5 \% \mathrm{Mg} / 5 \mathrm{wt} \% \mathrm{Al}_{2} \mathrm{O}_{3}$ composite; (b) $\mathrm{Al}-4 \%$ $\mathrm{Cu}-2.5 \% \mathrm{Mg} / 5 \mathrm{wt} \% \mathrm{SiC}$ composite.

The particular failure modes that are observed and the process of evolution of the failure depend broadly on processing, matrix microstructure and reinforcement morphology and distribution in addition to the stress state [24].

\section{Conclusions}

From the present study the following conclusions can be drawn:

1) $5 \mathrm{wt} \% \mathrm{Al}_{2} \mathrm{O}_{3}$ and $\mathrm{SiC}$ particulate reinforced $\mathrm{Al}-4 \%$ $\mathrm{Cu}-2.5 \% \mathrm{Mg}$ matrix composites were successfully produced through stir casting process;

2) The scanning electron microscopy (SEM) results showed that reasonably well dispersed of particles with small porosity at some locations. In addition, some dele- 
terious reaction phases were observed at the interfaces of both test materials;

3) $\mathrm{Al}-4 \% \mathrm{Cu}-2.5 \% \mathrm{Mg}$ matrix reinforced with $\mathrm{SiC}$ exhibit $15.8 \%, 16.4 \%, 4.97 \%$ and $10.8 \%$ higher $0.2 \%$ proof stress, ultimate tensile strength, elastic modulus, and hardness, respectively. On the other hand, although the $\mathrm{Al}_{2} \mathrm{O}_{3}$ reinforced composite demonstrate some porosity, but the percentage elongation (ductility) was 31\% higher than the $\mathrm{SiC}$ reinforced composite;

4) The fracture surfaces study revealed that the Al-4\% $\mathrm{Cu}-2.5 \% \mathrm{Mg} / 5 \% \mathrm{SiC}$ composite showed a britle fracture surface, whereas the $\mathrm{Al}-4 \% \mathrm{Cu}-2.5 \% \mathrm{Mg} / 5 \% \quad \mathrm{Al}_{2} \mathrm{O}_{3}$ composite demonstrate the formation of some necking before tensile failure and which is an indicator of the presence of some ductility.

\section{Acknowledgements}

The authors greatly acknowledged Mr. R. K. Harit, Super Attendant of Foundry Workshop in Mechanical and Industrial Engineering Department of IITRoorkee, Mr. Baleshwer D. Sharma and Ravindra K. Kaushal, Lab Attendants in Foundry Workshop in Mechanical and Industrial Engineering Department of IITRoorkee, for their significant technical support in the preparation of matrix and composite materials. The authors wish to extend their acknowledgement to Mr. Jalpan Sing, Technical Officer in Welding Research Lab in Mechanical and Industrial Engineering Department of IITRoorkee, for his kindly help during optical microstructure and hardness tests.

\section{REFERENCES}

[1] A. M. S. Hamouda, S. Sulaiman, T. R. Vijayaram, M. Sayuti and M. H. M. Ahmad, "Processing and Characterisation of Particulate Reinforced Aluminium Silicon Matrix Composite," Journal of Achievements in Materials and Manufacturing Engineering, Vol. 25, No. 2, 2007, pp. 1-16.

[2] S. Y. Oh, J. A. Cornie and K. C. Russell, "Wetting of Ceramic Particulates with Liquid Aluminium Alloys: Part II. Study of Wettability," Metallurgical Transactions A, Vol. 20, 1989, pp. 533-541.

[3] A. K. Telang, A. Rehman, G. Dixit and S. Das, "Alternate Materials in Automobile Brake Disc Applications with Emphasis on Al Composites-A Technical Review," Journal of Engineering Research and Studies, Vol. 1, No. 1, 2010, pp. 35-46.

[4] J. Hashim, L. Looney and M. S. J. Hashmi, "Metal Matrix Composites: Production by the Stir Casting Method," Journal of Materials Processing Technology, Vol. 92, No. 93, 1999, pp. 1-7. doi:10.1016/S0924-0136(99)00118-1

[5] M. Singla, D. D. Dwivedi, S. Lakhvir and V. Chawla, "Development of Aluminium Based Silicon Carbide Particulate Metal Matrix Composite," Journal of Minerals \& Materials Characterization \& Engineering, Vol. 8, No. 6, 2009, pp. 455-467.
[6] J. C. Lee and K. N. Subramanian, "Effect of Cold Rolling on the Elastic Properties of $\left(\mathrm{Al}_{2} \mathrm{O}_{3}\right)$ p-Al Composite," Journal of Materials Science, Vol. 28, No. 6, 1993, pp. 15781584. doi:10.1007/BF00363352

[7] M. Tan, Q. Xin, Z. Li and B. Y. Zong, "Influence of SiC and $\mathrm{Al}_{2} \mathrm{O}_{3}$ Particulate Reinforcements and Heat Treatments on Mechanical Properties and Damage Evolution of Al-2618 Metal Matrix Composites," Journal of Materials Science, Vol. 36, No. 8, 2001, pp. 2045-2053. doi:10.1023/A:1017591117670

[8] A. Sakthive, R. Palaninathan, R. Velmurugan and P. R. Rao, "Production and Mechanical Properties of SiCp Particle-Reinforced 2618 Aluminium Alloy Composites," Journal of Material Science, Vol. 43, 2008, pp. 7047-7056.

[9] E. Bayraktar, J. Masounave, R. Caplain and C. Bathias, "Manufacturing and Damage Mechanisms in Metal Matrix Composites," Journal of Achievements in Materials and Manufacturing Engineering, Vol. 31, No. 2, 2008, pp. 294-300.

[10] W. C. Harrigan Jr., "Commercial Processing of Metal Matrix Composites," Materials Science and Engineering $A$, Vol. 244, No. 1, 1998, pp. 75-79. doi:10.1016/S0921-5093(97)00828-9

[11] H. R. Saleh, "Mechanical Properties of the Modified Al12\%Si Alloy Reinforced by Ceramic Particles," Engineering and Technology Magazine, Vol. 28, No. 2, 2010, pp. 289-290.

[12] J. J. Lewandowski and C. Liu, "Effects of Matrix Microstructure and Particle Distribution on Fracture of an Aluminium Metal Matrix Composite," Materials Science and Engineering A, Vol. 107, 1989, pp. 241-255. doi:10.1016/0921-5093(89)90392-4

[13] K. M. Shorowordi, T. Laoui, A. S. M. A. Haseeb, J. P. Celis and L. Froyen, "Microstructure and Interface Characteristics of $\mathrm{B}_{4} \mathrm{C}, \mathrm{SiC}$ and $\mathrm{Al}_{2} \mathrm{O}_{3}$ Reinforced $\mathrm{Al}$ Matrix Composites: A Comparative Study," Journal of Materials Processing Technology, Vol. 142, No. 3, 2003, pp. 738743. doi:10.1016/S0924-0136(03)00815-X

[14] G. B. V. Kumar, C. S. P. Rao and N. Selvaraj, "Mechanical and Tribological Behaviour of Particulate Reinforced Aluminium Metal Matrix Composites-A Review," Journal of Minerals \& Materials Characterization \& Engineering, Vol. 10, No. 1, 2011, pp. 59-91.

[15] I. Sahin and A. A. Eker, "Analysis of Microstructures and Mechanical Properties of Particle Reinforced $\mathrm{AlSi}_{7} \mathrm{Mg}_{2}$ Matrix Composite Materials," Journal of Materials Engineering and Performance, Vol. 20, No. 6, 2011, pp. 1090-1096. doi:10.1007/s11665-010-9738-6

[16] R. Ehsani and S. M. S. Reihani, "Aging Behavior and Tensile Properties of Squeeze Cast Al 6061/SiC Metal Matrix Composites," Scientia Iranica, Vol. 11, No. 4, 2004, pp. 392-397.

[17] K. B. Lee, H. S. Sim and H. Kwon, "Reaction Products of Al/TiC Composites Fabricated by the Pressureless Infiltration Technique," Metallurgical and Materials Transactions A, Vol. 36, No. 9, 2005, pp. 2517-2527. doi:10.1007/s11661-005-0125-0

[18] K. B. Lee, Y. S. Kim and H. Kwon, "Fabrication of Al-3 Wt Pct Mg Matrix Composites Reinforced with $\mathrm{Al}_{2} \mathrm{O}_{3}$ 
and $\mathrm{SiC}$ Particulates by the Pressureless Infiltration Technique," Metallurgical and Materials Transactions A, Vol. 29A, 1998, pp. 3087-3095.

[19] A. A. Hamid, P. K. Ghosh, S. C. Jain and S. Ray, "Processing, Microstructure, and Mechanical Properties of Cast In-Situ $\mathrm{Al}(\mathrm{Mg}, \mathrm{Ti})-\mathrm{Al}_{2} \mathrm{O}_{3}\left(\mathrm{TiO}_{2}\right)$ Composite," Metallurgical and Materials Transactions A, Vol. 37A, 2006, pp. 469-480.

[20] S. N. Aqida, M. I. Ghazali and J. Hashim, "Effects of Porosity on Mechanical Properties of Metal Matrix Composite: An Overview," Jurnal Teknologi A, Vol. 40A, 2004, pp. 17-32.

[21] M. Kok, "Production and Mechanical Properties of $\mathrm{Al}_{2} \mathrm{O}_{3}$ Particle-Reinforced 2024 Aluminium Alloy Composites," Journal of Materials Processing Technology, Vol. 161, No. 3, 2005, pp. 381-387. doi:10.1016/j.jmatprotec.2004.07.068
[22] A. E. Karantzalis, S. Wyatt and A. R. Kennedy, "The Mechanical Properties of Al-TiC Metal Matrix Composites Fabricated by a Flux-Casting Technique," Materials Science and Engineering, Vol. 237, No. 2, 1997, pp. 200206. doi:10.1016/S0921-5093(97)00290-6

[23] A. Daoud, T. E. Bitar and A. A. E. Azim, "Tensile and Wear Properties of Rolled Al5Mg- $\mathrm{Al}_{2} \mathrm{O}_{3}$ or C Particulate Composites," Journal of Materials Engineering and Performance, Vol. 12, No. 4, 2003, pp. 390-397. doi:10.1361/105994903770342908

[24] Y. Li, K. T. Ramesh and E. S. C. Chin, "Comparison of the Plastic Deformation and Failure of A359/SiC and 6061-T6/ $\mathrm{Al}_{2} \mathrm{O}_{3}$ Metal Matrix Composites under Dynamic Tension," Materials Science and Engineering A, Vol. 371, No. 1-2, 2004, pp. 359-370. doi:10.1016/j.msea.2004.01.008 